\title{
EFL Learning Styles Used by Female Undergraduate Students and Its Relationship to Achievement Level
}

\author{
Wafa Ismail Saud ${ }^{1}$ \\ ${ }^{1}$ Faculty of Languages and Translation, King Khalid University, Abha, Saudi Arabia \\ Correspondence: Wafa Ismail Saud, Faculty of Languages and Translation, King Khalid University, Abha, Saudi \\ Arabia.
}

Received: May 15, 2018 Accepted: September 10, 2018 Online Published: November 28, 2018

doi:10.5539/ells.v8n4p30 URL: https://doi.org/10.5539/ells.v8n4p30

\begin{abstract}
The aim of the study was to investigate the preferred learning styles of undergraduate Saudi students at King Khalid University, Saudi Arabia and to examine the influence of achievement level on the choice of learning styles. A total of 110 undergraduate students participated in the study. They were in their third year of study and were majoring in English. Data was collected by means of a questionnaire and by an English achievement test. Reid's (1987) questionnaire was used to determine the students' preferred learning styles. It identifies six learning styles referred to as perceptual learning styles; they are visual learners, auditory learners, kinesthetic learners, tactile learners, group learners and individual learners. An English achievement test was conducted to classify students according to their academic grade. The results showed the preferred learning styles used by undergraduate Saudi students at KKU. The order of the preferred learning styles based on sensory channels was as follows: visual, tactile, kinesthetic and finally the least frequent one was auditory, furthermore, the results revealed that students prefer individual learning more than group learning. Besides that, the findings also indicated that there was no statistically significant relationship between the learning styles and achievement level except with the group learning style which was used by students who got grade Excellent or Very Good. The study concluded by providing some possible implications of the study for English teachers.
\end{abstract}

Keywords: auditory, kinesthetic, sensory, social, tactile, visual, group, individual

\section{Introduction}

There is a change in moving from teacher-centered approach to student-centered approach. People learn differently and the learning style is one of the influential elements that shows individual differences in EFL learning. It is noticeable that there are many ways for learning and students prefer some ways more than others. There is no preferable or inferior learning style; each has its strengths and weaknesses. An awareness of students learning styles would help teachers formulate more effective pedagogy and adapt their teaching methods to fit all students.

\subsection{Statement of the Problem}

Among the various factors that may hinder the processing of information is the mismatch between learning style preferences and teaching style (Ellis, 1989). There is a general acceptance that every individual approaches a learning task with a preferred mode of learning that has an impact on the learning outcomes. Keefe (1991) states that it is important for teachers to know how their students learn in order to improve students' achievement. Strenberg (1997) explains that awareness of students learning style can benefit teachers to match their teaching to learners' preferences. The low achievement of EFL students may be due to the inconsistency in the learning and teaching styles. Teachers are also confronted with low grades and poor attendance. It is essential to identify the learning styles of EFL students and examine the relationship between their learning styles and academic achievement. Thus, teachers can adapt their teaching styles to meet the learning styles of the students. Teachers can vary their activities to cover all of their students' learning preferences.

\subsection{Research Objectives}

There are two goals for this study:

A) To identify the learning styles used by Saudi undergraduate students. 
B) To examine the relationship between learning style preferences and achievement level of the students.

\subsection{Research Questions}

The study intends to answer the following questions:

A) What are the preferred learning styles of Saudi undergraduate students?

B) What is the relationship between learning style preferences and achievement level?

\subsection{Significance of the Study}

Students' success is influenced by the use of learning styles (Marshal, 1997). This study will provide the bases for identifying the learning styles preferred by Saudi undergraduate students. The outcome of this study will help weak Saudi undergraduate students excel in their academic studies by following certain styles. The study will also contribute to the literature of learning styles. It will provide a theoretical and practical framework for preferred learning styles used by Saudi undergraduate students. The findings of this study will have great implications for ESP teachers to adapt their methods of teaching and materials to cope with students' preference of learning styles. Ellis (1989) affirms that matching the learning and teaching styles has a great impact on the students' academic performance level.

\section{Theoretical and Practical Application}

\subsection{Definition of Learning Styles}

Every student approaches any learning task with a preferred way of learning. This unique way is called an individual learning style. Learning styles have received considerable attention in recent years to identify learning style preferences and its relationship to achievement level.

The term learning style is defined in a variety of ways. The most widely used definition is Keefe (1979) who defines learning styles as "cognitive, affective, and physiological traits that are relatively stable indicators of how learners perceive, interact with and respond to the learning environment" (P.4). Another definition was provided by Reid (1995) who states that learning styles are related to the qualities of the learners that help them process new information. Similarly, Grasha (1996) states that learning styles are "Personal qualities that influence students' ability to acquire information, to interact with peers and the teacher, and otherwise to participate in learning experiences" (P.40). Likewise Marshal (1997) defines learning style as the preferred pattern used by the students that helps them attain knowledge.

There are several categories of learning styles. The focus of this study is on the perceptual learning styles, as perception is the core process in the acquisition of knowledge. Reid (1987) states that perceptual learning styles are "the variations among learners in using one or more senses to understand, organize and retain experience" (P.89). Similarly, Davis (2007) defines perceptual learning styles as "the means by which learners extract information from their surroundings through the use of their five senses" (P.46). According to Reid (1987) perceptual learning styles refer to both physiological and social interactions. Perceptual learning styles are divided into six categories: four are concerned with the sensory channels i.e. visual, auditory, kinesthetic and tactile, and two are devoted to the learners' social factors i.e. individual and group.

The sensory channels through which perception takes place are:

- Visual learners prefer to learn via their vision to process information.

- Auditory learners like to learn by listening to lectures and discussions.

- Kinesthetic learners prefer to learn through body movement.

- $\quad$ Tactile learners like to work with hands, they like learning by doing something.

The social channel through which learning takes place:

- Social learners prefer to work with others and learn in a cooperative classroom.

- Individual learners like to learn by themselves. They learn in a competitive classroom.

\subsection{Empirical Studies on Perceptual Learning Styles and Achievement Level}

Improving students' academic achievement was the aim of researchers and teachers. Studies related to the relationship between learning style preferences and achievement level showed apparent inconsistency in results. A number of studies revealed that there is a significant relationship between perceptual learning styles and achievement level.

It is seen in the study conducted by Lee and Kim (2014), to identify the learning style of 496 Korean university 
EFL learners, and to explore the relationship between learning styles and academic achievement. The results revealed that Korean students had a stronger preference for auditory style, followed by visual and individual learning styles. On the other hand, kinesthetic, and group styles were least frequent. In addition, the results demonstrated that visual, tactile, kinesthetic and individual style preferences were found to be positively correlating with achievement.

Another study was conducted by Alsamadani (2012) to identify the learning style preferences of 113 undergraduate dental students (male and female), at King Saud University in Riyadh, Saudi Arabia. The study aimed at examining the relationship of learning styles to gender and past academic performance. A questionnaire was used to collect the data. It consists of four sections, i.e. the visual, aural, read-write, and kinesthetic. Results showed that more than half of the students had multimodal learning preferences. The most common learning style was aural, followed by kinesthetic. Besides, there was a statistical significant difference in the mean values of students' GPA in the preparatory year and their learning styles. Students with multiple learning style preferences had higher mean values of GPA and vice versa.

Alkhtani (2011) investigated the use of perceptual learning styles of 100 Saudi EFL college students, to determine whether their perception of their learning styles is a predictor of academic persistence and success in online-bases and in class-based environments. The instruments used in the study were Reid's (1995) questionnaires, and interviews. The findings indicated that the order of the preferred learning styles was as follows: tactile, auditory, visual, group, kinesthetic and individual. In addition, there is a relationship between the students' learning style preferences and their success and positive experience.

On the other hand, other studies confirmed that learning style had no effects on achievement. Montemayor et al. (2009) carried out a study relating learning style preferences and achievement among first year university students. The findings indicated that learning styles were found to be negatively correlating with achievement.

Similarly, Al-Zayed (2017) examined the preferred perceptual learning style used by 166 tenth-grade Jordanian EFL students. Besides, the study also investigated the relationship between the students' learning styles and their academic achievement. Data were collected by means of a questionnaire and from students' grades in the final examination. The findings revealed that there is no relationship between learning style preferences and achievement level. Furthermore, the most preferred learning style was auditory and the least were kinesthetic and visual styles.

Finally, EL Ghouati (2017) conducted a study to examine the relationship between learning styles and English achievement in a technology-based learning environment. The participants were 81 Moroccan EFL university students. A questionnaire and an achievement test were the instruments used. The findings indicated that the learning styles were found to be negatively correlating with achievement.

\section{Methodology}

\subsection{Research Design}

Quantitative research was conducted as statistical techniques were involved. The researcher used a questionnaire and an achievement test as a main data gathering method.

\subsection{Participants}

The participants in this study were 110 female undergraduate students from King Khalid University, Saudi Arabia. Their ages ranged between 18 and 25. They were all third year students majoring in English. The data was collected in semester two of the academic year 2016/2017. Four intact classrooms were involved in the study.

\subsection{Data Collection Procedures}

The techniques used for eliciting information were a questionnaire survey and an achievement test. A self-reporting questionnaire was used to identify the EFL learning styles used by female undergraduate students. The questionnaire was designed by Reid (1987). No modification was required except adding some questions for eliciting background information. The questionnaire consists of six classifications, visual, auditory, kinesthetic, tactile, group and individual learning preferences. Five statements are allocated for each classification. The students had to tick $(\sqrt{ })$ in the appropriate column representing the following: SA= Strongly Agree, A= Agree, $\mathrm{N}=$ Neutral, $\mathrm{D}=$ Disagree and $\mathrm{SD}=$ Strongly Disagree.

The questionnaire was piloted with ten students at King Khalid University. The pilot study showed that students had no problems in reading or comprehending the questionnaire.

A final achievement test was administered to $110 \mathrm{EFL}$ undergraduate students. It was divided into three sections, 
reading, writing, and grammar. Their achievement scores were combined with the answers of the questionnaires.

\section{Results}

Data analysis was carried out using SPSS. The analysis consisted of descriptive statistics (means and frequencies). It also consisted of comparing means using Analysis of Variance (ANOVA).These statistical procedures help provide answer to research question $1 \& 2$.

In the data analysis procedures, the findings from the questionnaires and the achievement test were divided into the following components:

a) Description of the learning styles used by third-year English majors at King Khalid University.

b) The influence of achievement level on their choice of learning style.

c) Recommendations that could improve EFL teaching.

\subsection{Description of the Learning Styles Used by Third-Year English Majors at King Khalid University}

Analysis of the data indicated that EFL undergraduate students prefer to use certain learning styles more frequently than others. Means of the perceptual learning styles based on the sensory channels demonstrate which learning styles were favored by the undergraduate students as shown in Table 1.

Table 1. Type and mean score of the most frequent styles used based on the sensory channels

\begin{tabular}{lllll}
\hline Report & & & & \\
& Auditory & Kinesthetic & Visual & Tactile \\
\hline Mean & 2.11 & 2.19 & 2.25 & 2.21 \\
$\mathrm{~N}$ & 110 & 110 & 110 & 110 \\
Std. Deviation & .47 & .78 & .69 & .69 \\
\hline
\end{tabular}

Table 1 shows that the EFL undergraduate students used all types of learning styles included in the questionnaire, but in different degrees. The most frequent style used based on the sensory channels was visual $(2.25 \%)$, followed by tactile $(2.21 \%)$, then by kinesthetic $(2.19 \%)$, and finally the least used was auditory $(2.11 \%)$.

For analysis of the perceptual learning style based on social factors, descriptive statistics was carried out as shown in Table 2.

Table 2. Type and mean score of the most frequent styles based on the social factors

\begin{tabular}{lll}
\hline Report & Group & Individual \\
\hline Mean & 2.49 & 2.59 \\
$\mathrm{~N}$ & 110 & 110 \\
Std. Deviation & 1.04 & .91 \\
\hline
\end{tabular}

The analysis indicated that students showed strong preference in individual learning (2.59\%), more than group learning (2.49\%).

\subsection{The Influence of Achievement Level on the Choice of Language Learning Strategies}

In order to determine the relationship between the use of learning styles and language performance, the students' language performance was gauged by administering an achievement test on Saudi third year English undergraduates which included listening, reading, writing and grammar. The questionnaire was distributed to the same students who took the achievement test. Table 3 shows the data obtained from the questionnaire that measured the students' learning style and was compared with the data obtained from the achievement test. 
Table 3. Type and mean score of the most frequent sensory styles used with regard to achievement level

\begin{tabular}{llllll}
\hline Report & & & & & \\
Grade & & Auditory & Kinesthetic & Visual & Tactile \\
\hline \multirow{3}{*}{ Excellent } & Mean & 2.14 & 2.50 & 2.30 & 2.43 \\
& $\mathrm{~N}$ & 14 & 14 & 14 & 14 \\
& Std. Deviation & .40 & .69 & .78 & .64 \\
Very Good & Mean & 2.03 & 2.26 & 2.28 & 1.98 \\
& $\mathrm{~N}$ & 19 & 19 & 19 & 19 \\
& Std. Deviation & .44 & 1.18 & .69 & .60 \\
Good & Mean & 2.12 & 2.19 & 2.11 & 2.23 \\
& $\mathrm{~N}$ & 32 & 32 & 32 & 32 \\
& Std. Deviation & .52 & .72 & .65 & .63 \\
Fair & Mean & 2.21 & 2.11 & 2.33 & 2.32 \\
& $\mathrm{~N}$ & 30 & 30 & 30 & 30 \\
& Std. Deviation & .46 & .66 & .71 & .82 \\
Fail & Mean & 2.00 & 2.00 & 2.31 & 2.05 \\
& $\mathrm{~N}$ & 15 & 15 & 15 & 15 \\
& Std. Deviation & .48 & .53 & .68 & .59 \\
Total & Mean & 2.11 & 2.19 & 2.25 & 2.21 \\
& $\mathrm{~N}$ & 110 & 110 & 110 & 110 \\
& Std. Deviation & .47 & .78 & .69 & .69 \\
\hline
\end{tabular}

The results showed that the dominant learning style used by excellent students is kinesthetic $(2.50 \%)$, tactile $(2.43 \%)$, and visual $(2.30 \%)$. The least style used was auditory $(2.14 \%)$.

Similarly, the students with "very good" grade, used visual $(2.28 \%)$, as the most frequent, followed by kinesthetic (2.26\%). The least styles used were auditory (2.03\%), and tactile (1.98\%).

On the other hand, students with "good" grade used tactile (2.23\%) as the most frequent, followed by kinesthetic $(2.19 \%)$. The least frequent ones were auditory $(2.12 \%)$ and visual $(2.11 \%)$.

Similarly, students with "fair" grade used visual $(2.33 \%)$ as the most frequent, followed by tactile $(2.32 \%)$, then auditory $(2.21 \%)$ and the least one is kinesthetic $(2.11 \%)$.

Finally, students with "fail" grade reported the use of visual $(2.31 \%)$ as the most frequent, then tactile (2.05\%), next auditory and kinesthetic $(2.00 \%)$.

Likewise, for analysis of the significance values of the means of categories of sensory learning styles and achievement level were determined on the basis of ANOVA as shown in Table 4.

Table 4. F value, degree of freedom and significant level for categories of sensory learning styles and achievement level

\begin{tabular}{|c|c|c|c|c|c|c|}
\hline \multicolumn{7}{|l|}{ ANOVA } \\
\hline & & Sum of Squares & df & Mean Square & $\mathrm{F}$ & Sig. \\
\hline \multirow{3}{*}{ Auditory } & Between Groups & .594 & 4 & .148 & .674 & .611 \\
\hline & Within Groups & 23.123 & 105 & .220 & & \\
\hline & Total & 23.717 & 109 & & & \\
\hline \multirow{3}{*}{ Kinesthetic } & Between Groups & 2.195 & 4 & .549 & .899 & .467 \\
\hline & Within Groups & 64.082 & 105 & .610 & & \\
\hline & Total & 66.277 & 109 & & & \\
\hline \multirow{3}{*}{ Visual } & Between Groups & .892 & 4 & .223 & .461 & .764 \\
\hline & Within Groups & 50.760 & 105 & .483 & & \\
\hline & Total & 51.652 & 109 & & & \\
\hline \multirow{3}{*}{ Tactile } & Between Groups & 2.417 & 4 & .604 & 1.297 & .276 \\
\hline & Within Groups & 48.909 & 105 & .466 & & \\
\hline & Total & 51.326 & 109 & & & \\
\hline
\end{tabular}

The results showed that the F-values are statistically insignificant at the 0.05 level. Thus, there were no significant differences in the means of the learning styles used by EFL undergraduate students with regard to 
achievement level.

Analysis of the data obtained regarding the relationship between social styles and achievement level using descriptive statistics is summarized in Table 5 .

Table 5. Type and mean score of the most frequent social styles used with regard to achievement level by EFL undergraduate students

\begin{tabular}{llll}
\hline $\begin{array}{l}\text { Report } \\
\text { Grade }\end{array}$ & & Group & Individual \\
\hline \multirow{3}{*}{ Excellent } & Mean & 3.14 & 2.11 \\
& $\mathrm{~N}$ & 14 & 14 \\
& Std. Deviation & .70 & .87 \\
Very Good & Mean & 2.86 & 2.37 \\
& $\mathrm{~N}$ & 19 & 19 \\
& Std. Deviation & 1.01 & .90 \\
Good & Mean & 2.49 & 2.56 \\
& $\mathrm{~N}$ & 32 & 32 \\
& Std. Deviation & 1.16 & .88 \\
Fair & Mean & 2.21 & 2.88 \\
& $\mathrm{~N}$ & 30 & 30 \\
& Std. Deviation & .91 & .88 \\
Fail & Mean & 1.96 & 2.79 \\
& $\mathrm{~N}$ & 15 & 15 \\
& Std. Deviation & .95 & .89 \\
Total & Mean & 2.49 & 2.59 \\
& $\mathrm{~N}$ & 110 & 110 \\
& Std. Deviation & 1.04 & .91 \\
\hline
\end{tabular}

Table 5 shows that the most frequent style based on social channels used by excellent and very good students was group learning. On the contrary, students with grade good, fair and fail used individual style most.

Another analysis of the significance values of the means of categories of social learning styles and achievement level were determined on the basis of ANOVA as shown in Table 6.

Table 6. F value, degree of freedom and significant level for categories of social learning styles and achievement level

\begin{tabular}{lllllll}
\hline ANOVA & & & & & \\
& & Sum of Squares & $\mathrm{df}$ & Mean Square & $\mathrm{F}$ & Sig. \\
\hline \multirow{3}{*}{ Group } & Between Groups & 15.123 & 4 & 3.781 & 3.854 & .006 \\
& Within Groups & 103.004 & 105 & .981 & & \\
& Total & 118.127 & 109 & & & \\
\multirow{4}{*}{ Individual } & Between Groups & 7.240 & 4 & 1.810 & 2.311 & .063 \\
& Within Groups & 82.222 & 105 & .783 & & \\
& Total & 89.462 & 109 & & & \\
\hline
\end{tabular}

Table 6 shows that the F-values are statistically significant at the 0.05 level for group style. Thus, there was a statistically significant relationship between the use of group learning style and achievement level.

In summary, the auditory style was used by most students of all grades as the least, or nearly the least used style. The visual learning style was not consistent with grades. Kinesthetic style was used at a high level by students with grades excellent, good and very good, while students with low grades and failures used it as the least frequent one.

On the other hand, the findings indicated that only students with grades excellent and very good used the group style as their most frequent one, and students with all the other grades used the individual style most. The group style is used the least frequent by the failures.

\section{Discussion}

In the examination of the styles based on the sensory channels, students showed that they prefer to learn by 
visualizing words, they must have written directions if they are to function well in the classroom. They can recall information best if they are equipped with visual aids such as PowerPoint presentations, pictures and handouts. Visual sense is a major part of their senses preferences. Students who chose auditory as the least frequent style probably lack confidence in remembering things heard in class or they feel bored listening to others speak. This finding is in contradiction with Al-Zayed (2017) study, which revealed that the most preferred learning style was auditory. A possible explanation for this finding refers to the fact that students are taught at the university using PowewPoint presentations which help visual style learners, or maybe it is related to the cultural context of the students. Students prefer tactile and kinesthetic to retain knowledge at nearly the same level as they prefer to do so through body movement and through using a hand's on approach. They like to be involved physically in the learning process. They like to take notes or underline important information. In addition, with regard to social factors, students showed that they like to learn individually. This result indicated that students need more practice on cooperative learning to develop both learning and social skills.

In investigating the nature of relationship between the sensory factors and achievement level, the findings showed that excellent, very good and good students all have a stronger preference for kinesthetic learning style. It is very difficult for them to sit still doing nothing. They are active and like to learn by doing. However, the findings of ANOVA displayed a non-significant relationship in the use of sensory learning styles and achievement level. This finding is confirmed by the study of Ghouti (2017) which indicated that achievement level is not related to learning style preference. On the other hand with regard to social factors and achievement level, the results indicated that there was a significant relationship between the use of group learning and achievement level. Excellent and very good students used group learning more than individual learning. Maybe this is because students are mature in their study style as they realize that language needs to be practiced for improvement.

\section{Conclusion}

The current study identified the preferred learning styles of undergraduate Saudi students. In addition, it examined the relationship between their learning styles and their achievement levels. The findings showed that undergraduate Saudi students prefer the visual learning style most and the auditory learning style least. Furthermore, they prefer individual learning more than group learning. With regards to the nature of the relationship between learning styles and achievement levels, the results indicated that there was no statistically significant relationship between the sensory learning styles and achievement level. On the other hand, there was a statistically significant relationship between the social learning style and achievement level. Students with group learning style got grade excellent or very good.

The findings of the present study highlight some implications for EFL teachers who may have an interest in the results. They can plan their instruction according to the students' preferences more than following their preferred mode of teaching and they can accommodate activities for their students' preferred learning styles.

For example: Visual learners prefer to look for written information from books or from the internet; they prefer handouts, PowerPoint presentations, charts and graphs. They avoid oral production. They take notes in the classroom.

Auditory learners enjoy reading aloud and verbal discussions. They master new information by listening and repeating with others. So recording lectures by the use of new technology is very helpful.

Kinesthetic learners use movement in order to learn. They prefer to practice new behavior or skill such as role-playing.

Group learners prefer to cooperate in doing the activities; they can learn from each other and develop social skills.

Individual learners prefer challenging questions. They like competitive learning. They like teachers to recognize their individual accomplishment.

Tactile learners like to learn through touching. They cannot understand something abstract. They read "hands on" activity to learn.

In sum, Teachers can use a multiple style approach to help students learn successfully, and they should raise the students 'awareness of the concept of learning styles.

\section{Acknowledgments}

I am thankful to the reviewers for their advice and useful comments throughout the course of my study. I am deeply grateful to the participants in my study for their cooperation and desire to help. 


\section{References}

Alkhtani, M. (2011). Learning styles of EFL Saudi college-level students in online and traditional educational environments (doctoral dissertation). Indiana University of Pensylvania.

AlSamadani, H. (2012). Learning style preferences of First-Year dental students at king Saud University in Riyadh, Saudi Arabia: Influence of gender and GPA. The International Journal of Learning in Higher Education, 19(2), 1-9.

AlZayed, N. (2017). An investigation of learning style preferences on the students'academic achievements of English. International Journal of English Linguistics, 7(5), 176-183. https://doi.org/10.5539/ijel.v7n5p176

Davis, S. E. (2007). Learning styles and memory. Institute of Learning Style Research Journal, 1, 46-51.

Dornyei, Z. (2005). The psychology of the language learner: Individual differences in second language acquisition. Mahwah, NJ: Lawrence Erlbaum Associates, Inc. http://dx.doi.org/10.1177/0261927X05281424

EL-Ghouati, A. (2017). Examining the relationship between E-Learning styles and achievement in English among Moroccan University students. Arab World English Journal, 8(2), 323-332. https://dx.doi.org/10.24093/awej/vol18no2.23

Ellis, R. (1989). Classroom learning styles and their effect on second language acquisition: A study of two learners. System, 17(2), 249-261.

Grasha, A. F. (1996). Teaching with style. Pittsburgh, PA: Alliance

Keefe, J. W. (1979). Learning style: An overview. NASSP's Student learning styles: Diagnosing and proscribing programs (pp. 1-17). Reston, VA: National Association of Secondary School Principles.

Keefe, J. W. (1991). Learning style: Cognitive and thinking skills. Reston, VA: National Association of Secondary School Principles.

Lee, B., \& Kim, H. (2014). What can we learn from our learners' learning styles. English Language Teaching, 7(9), 118-131. https://dx.doi.org/10.5539/elt.v7n9p118

Marshal, C. (1997). Learning styles and learning success-What every educator should know. Texas Tech University, Lubbock, TX.

Montemayor, E., Aplaten, M., Mendoza, G. C., \& Perey, G. M. (2009). Learning styles of high and low academic achieving freshman teacher education students: An application of the Dunn and Dunn's Learning style Model. University of the Cordilleras Journal, 1(4), 58-71.

Reid, J. (1987). The Learning style preferences of ESL students. TESOL Quarterly, 21(1), 87-109.

Sternberg, R. J. (1997). Thinking styles. Cambridge, UK: Cambridge University Press.

Tumposky, N. (1984). Behavioral objectives, the cult of efficiency, and foreign language learning: are they compatible? TESOL Quarterly, 18, 295-310.

\section{Copyrights}

Copyright for this article is retained by the author, with first publication rights granted to the journal.

This is an open-access article distributed under the terms and conditions of the Creative Commons Attribution license (http://creativecommons.org/licenses/by/4.0/). 